\title{
Impact of Foreign Exchange rate on stock prices
}

\author{
Maheen ${ }^{1}$ jamil , ${ }^{2} \mathrm{Mr}$ Naeem Ullah \\ ${ }^{I}$ (Management Sciences, Foundation University Institute of Engineering \& Management Sciences, Pakistan)
}

\begin{abstract}
Foreign exchange fluctuations have been found in the literature review to have an impact on the stock market return and the fluctuations in the stock prices. This research uses the cointegration technique to analyze the impact of USD to PKR exchange rate on the stock return market in Pakistan. The stock market return has been studied by KSE 100 Index. The results show that a relationship between the two variables exists in the short run in Pakistan.
\end{abstract}

Keywords-Exchange Markets, stock prices, Pakistan

\section{Introduction}

Stock market return is one of the most relevant and most important metric for the management and the shareholders of the organizations. The study on the factors that impact the share prices is flocking the research databases mostly because the theorist and the applicants want to optimize the management processes and thus provide a guaranteed and stabilized performance of the stock. One factor that impacts the return on stocks and the interest of investors in the stock is the foreign exchange rate.

Foreign exchange return is also important in the context of macroeconomic management of a country meaning to say that if a relationship between the foreign exchange rate and the stock market return is found to exist, then the government has the opportunity to manage the exchange rate and thus the return on the stock market. Moreover, through the establishment of this relationship, the investors will be able to get another element of predictability in the fluctuations of stock market returns.

\section{Literature Review}

As far as the existence of literature on market returns and forecasting stock returns is concerned, the amount is found to be considerably high (Ferreira and Santa-Clara, 2011). A number of factors have been of interest when it comes to forecasting stock market return for example the macroeconomic variables, the corporate actions and finally the measure of risk and the studies find that there is a predictable component in stock market return that the investors can find and use to stabilize their returns to a greater extent. Certain critique however exists to the researches and the forecasting models that exist. For example Goyal and Welch (2008) studied the out of sample performance of a list of apparent predictors of stock market return and find the historical mean to have a better out of sample performance in predicting the stock market returns than the traditional regressions used for forecasting purposes. So what Goyal and Welch (2008) are saying is that the use of traditional predictive regression models would not have helped the investor in either attaining valuable information regarding the stock return patterns or to make profits on time.

Bermer and Hiraki (1999) say that there has been a lot of interest shown by interest to know whether there exists a predictable component in the short term stock return or not. One of the reasons for this interest is that the researchers want to either confirm or reject the assumed rationality of individual investors and the efficiency of the stock market. Those who do have faith in the rationality of investors and efficiency of the market, seek to study the short term return patterns of the stock in order to give evidence on the subtle market microstructure issues.

For the purpose of assessing the expected returns, uncertain changes in the investment opportunity have been found to play a strong role in ascertaining the demand of the asset by the potential investors (Cox, Ingersoll and Ross, 1985). In this regards, Chiang and Doong (1999) says that financial volatility is a factor that needs to be considered significantly for exaplining the stock returns.

\section{Exchange Rate}

As far as quantifying the expectation of the exchange rate are concerned, Marey (2004) says on the basis of a survey data that long term expectations are not only heterogeneous but are also not effectively described by the rational expectations. In his own research, Marey (2004) tried to investigate the level of plausibility of standard exchange rate expectations mechanism which in an artificial economy are found to be favored by heterogeneous traders, the research concludes that adaptive expectations market exhibits more serial correlation because it bandwagons the expectations market. Secondly, the extrapolative expectations market 
sometimes generates extreme returns and thus cannot be empirically plausible and finally, the regressive expectations market reproduces stylized facts of empirical quarterly exchange rates.

Tsen (2011) says that the real exchange rate has been found to play an important role in the investment determination and the international trade systems as the appreciation of real exchange rate can lead to retarded exports, a change in the amount of debt payment that needs to be done and a growth of inflow of foreign direct investment. The economies overall can be affected by the changes in the exchange rate.

For this research however, the impact of exchange rate changes on the stock returns has been considered.

\section{The Impact of Exchange Rate Changes on the Stock Returns}

The relationship with the US dollar and the Stock Exchange Index has been studied by Wu et al (2012) who have focused their research on the Philippine Stock Exchange. According to the authors, such a research can actually help in guiding the government of countries to macro manage the investor returns on the stocks and thus in effect control the inflow of foreign direct investment into the country. Focusing further on the issue, Bahani-Oskooee and Sohrabian (2006) use the granger causality technique along with the co integration technique to analyze the results of exchange rates and stock prices by using the S\&P 500 index. The results show that not only the relationship exists only in the short run, it is also bidirectional. Moving on, Branson (1983) discusses his stock oriented model of exchange rates and emphasizes on the fact that the exchange rates serve to equate the supply and demand for assets including the stocks and the bonds. Yau and Nieh (2008) note that even though the existence of a relationship is often signified by the researchers between the stock exchange returns and the exchange rates, the length and the direction of the relationship is often an element of further debate. Interestingly, using the granger causality and the relationship between the financial assets and exchange rates of USA and Japan, Yau and Nieh (2008) find that there is no short term causal relationship between the two however in the long run a positive relationship has been found to exist.

Kim (2003) uses the error correction technique and the co integrating system to investigate whether a long term relationship exists between the exchange rates and the stock prices in the United States. The data set used is the S\&P 500 which yields that there is a negative relationship that exists for the stock returns in USA with the value of the dollar. Finally, Lin (2012, p. 161) analyzes the comovement of the exchange rates and the stock prices in the Asian markets and finds that

"Results have suggested that the comovement between exchange rates and stock prices becomes stronger during crisis periods than during tranquil ones, in terms of long-run co-integration and short-run causality, which is consistent with contagion or spillover between exchange rates and stock prices during the former type of period."

This means that the government when trying to control the crisis period should try to stimulate growth and keep investment attractive.

\section{Methodology}

In order to test our hypothesis monthly KSE 100 index data from Karachi Stock Exchange (KSE) was obtained from 1998 to 2009. Returns of index were calculated by using following formula:

(1)

$$
\text { mret }=\ln \left(\frac{\text { mret }_{t}}{\text { mret }_{t-1}}\right)
$$

Further monthly Real exchange rates (EXT) were obtained from IFS CD Rom from 1998 to 2009. Real exchange rate was proffered in order to investigate change that is purely due to exchange rate itself and not contaminated by inflation. The analysis period was confined from 1998 to 2009 primarily due to nonavailability of the former prior to 1998. Further the IFS CD ROM was updated to give exchange rate information till June 2010. Since we wanted to obtain data yearly, six months data in 2010 was unavailable. Thus we decided to calculate variables from 1998 to 2009, where complete yearly information was available.

Our sample was time series and it has inherent problems of non-stationarity that leads to spurious regression. Thus we conducted stationarity tests using Phillip Peron(PP) tests for stationarity. The results of PP are more robust than Augmented Decke fuller test for stationarity (Gujrati, 2003). Thus after we were confirmed that data is stationary, we will check for co integration and also vector error correction test cannot be conducted until there is a long term affiliation between variables. The co integration tests will reveal whether there exist a long term relationship between stock market returns and real exchange rates. Once the co integration tests confirm long term relationship, we will conduct vector error correction model. After that we will run ordinary least square regression using following equation to see if short term impact exist or not.

(2) $\mathrm{D}($ MRET $)=\mathrm{C}(1) *\left(\operatorname{MRET}(-1)+\beta_{1} * \operatorname{EXT}(-1)+\beta_{2} * @ \operatorname{TREND}(1)+\mathrm{C}\right)+\mathrm{C}(2) * \mathrm{D}(\operatorname{MRET}(-1))+$ $\mathrm{C}(3) * \mathrm{D}(\mathrm{EXT}(-1))+\mathrm{C}(4) * \mathrm{D}(\operatorname{MRET}(-2))+\mathrm{C}(5) * \mathrm{D}(\mathrm{EXT}(-2))+\mathrm{C}(6)$

The portion of the model in parenthesis is co integrating while the rest of the equation is comprised of error correction term. Our variable of interest are $\mathrm{C}(3)$ and $\mathrm{C}(5)$. These are error correction terms representing 
previous month's change in exchange rates. Thus we will check if they have impact on returns by using Wald Test under following hypothesis;

$\mathrm{H}_{0}$ : Exchange rate change has no impact on Market returns in short term.

$\mathrm{H}_{1}$ : Exchange rate change has impact on Market Returns in short term.

Significant $\mathrm{p}$-values of less than .05 will indicate that we will accept $\mathrm{H}_{1}$. This acceptance will lead us to believe that in short term exchange rate fluctuations will impact stock market returns.

\section{Results and Discussion:}

Unit root test was conducted using Phillip Peron test for stationarity. The test was conducted under all assumptions i.e. with intercept, without intercept but trend and without intercept and trend. The results for both variables are summarized in tables 1.1 and 1.2.

Table 1.1: Unit Root Test for Market Returns

\begin{tabular}{|l|l|l|l|l|}
\hline ASSUMPTIONS & $\begin{array}{l}\text { PHILIPS PERRON TEST } \\
\text { STATISIC }\end{array}$ & \multicolumn{3}{|c|}{ CRITICAL VALUES } \\
\hline & & $\mathbf{1 \%}$ & $\mathbf{5 \%}$ & $\mathbf{1 0 \%}$ \\
\hline Intercept & -11.3802 & -3.477 & -2.8817 & -2.5774 \\
\hline Trend and intercept & -5.107754 & -4.263 & -3.4426 & -3.1457 \\
\hline NO intercept and No trend & -4.826372 & -2.5804 & -1.9422 & -1.6169 \\
\hline
\end{tabular}

Table 1.2: Unit Root Test for Change in Exchange Rate

\begin{tabular}{|l|l|l|l|l|}
\hline ASSUMPTIONS & $\begin{array}{l}\text { PHILIPS PERRON TEST } \\
\text { STATISIC }\end{array}$ & \multicolumn{3}{|c|}{ CRITICAL VALUES } \\
\hline & & $\mathbf{1 \%}$ & $\mathbf{5 \%}$ & $\mathbf{1 0 \%}$ \\
\hline Intercept & -7.840877 & -3.477 & -2.8817 & -2.5774 \\
\hline Trend and intercept & -7.81797 & -4.0245 & -3.4417 & -3.1452 \\
\hline NO intercept and No trend & -7.413119 & -2.58 & -1.9421 & -1.6169 \\
\hline
\end{tabular}

The results indicate that both variables are stationary under all three assumptions at level. This indicates that problem of non stationarity does not exist in our series and our series has constant variance. This helps us in predicting out of sample relationship and robustness is ensured. Further, since our variables are stationary at same level, we can safely check our variables for long term relationship. Thus after unit root we will carry out co integration tests to check for long term relationship.

\begin{tabular}{||ccccc||}
\hline $\begin{array}{l}\text { Dependent Variable: MRET } \\
\text { Method: Least Squares } \\
\text { Date: 08/11/12 Time: } 15: 40 \\
\text { Sample: } 1 \text { 144 } \\
\text { Included observations: } 144\end{array}$ & & & & \\
\hline \hline & & & & \\
\hline Variable & Coefficient & Std. Error & t-Statistic & Prob. \\
\hline \hline EXT & -4.571414 & 2.396577 & -1.907477 & 0.0585 \\
C & 0.016659 & 0.008992 & 1.852693 & 0.0660 \\
\hline \hline R-squared & 0.024983 & Mean dependent var & 0.011649 \\
Adjusted R-squared & 0.018117 & S.D. dependent var & 0.104142 \\
S.E. of regression & 0.103194 & Akaike info criterion & -1.690620 \\
Sum squared resid & 1.512160 & Schwarz criterion & -1.649372 \\
Log likelihood & 123.7246 & Hannan-Quinn criter. & -1.673859 \\
F-statistic & 3.638468 & Durbin-Watson stat & 1.956234 \\
Prob(F-statistic) & 0.058478 & & & \\
\hline
\end{tabular}




\subsection{Co integration Test}

Co integration test was conducted under all assumption. The result are summarized in table 1.4

\begin{tabular}{|c|c|c|c|c|}
\hline \multicolumn{5}{|c|}{$\begin{array}{l}\text { Date: } 08 / 11 / 12 \text { Time: } 15: 27 \\
\text { Sample (adiusted): } 6144 \\
\text { Included observations: } 139 \text { after adjustments } \\
\text { Trend assumption: Quadratic deterministic trend } \\
\text { Series: MRET EXT } \\
\text { Lags interval (in first differences): } 1 \text { to } 4\end{array}$} \\
\hline $\begin{array}{l}\text { Hypothesized } \\
\text { No. of CE(s) }\end{array}$ & Eigenvalue & $\begin{array}{l}\text { Trace } \\
\text { Statistic }\end{array}$ & $\begin{array}{l}0.05 \\
\text { Critical Value }\end{array}$ & Prob.*. \\
\hline $\begin{array}{l}\text { None } \\
\text { At most } 1^{*}\end{array}$ & $\begin{array}{l}0.286028 \\
0.081040\end{array}$ & $\begin{array}{l}58.57791 \\
11.74720\end{array}$ & $\begin{array}{l}18.39771 \\
3.841466\end{array}$ & $\begin{array}{l}0.0000 \\
0.0006\end{array}$ \\
\hline \multicolumn{5}{|c|}{$\begin{array}{l}\text { Trace test indicates } 2 \text { cointegrating eqn(s) at the } 0.05 \text { level } \\
\text { denotes rejection of the hypothesis at the } 0.05 \text { level } \\
\text { "MacKinnon-Haug-Michelis (1999) p-values }\end{array}$} \\
\hline \multicolumn{5}{|c|}{ Unrestricted Cointegration Rank Tost (Maximum Eigenvalue) } \\
\hline $\begin{array}{l}\text { Hypothesized } \\
\text { No. of CE(s) }\end{array}$ & Eigenvalue & $\begin{array}{c}\text { Max-Eigen } \\
\text { Statistic }\end{array}$ & $\begin{array}{c}0.05 \\
\text { Critical Value }\end{array}$ & Prob.** \\
\hline $\begin{array}{l}\text { None } \\
\text { At most } \\
\end{array}$ & $\begin{array}{l}0.286028 \\
0.081040\end{array}$ & $\begin{array}{l}46.83071 \\
11.74720\end{array}$ & $\begin{array}{l}17.14769 \\
3.841466\end{array}$ & $\begin{array}{l}0.0000 \\
0.0006\end{array}$ \\
\hline \multicolumn{5}{|c|}{$\begin{array}{l}\text { Max-eigenvalue test indicates } 2 \text { cointegrating eqn(s) at the } 0.05 \text { level } \\
\text { denotes rejection of the hypothesis at the } 0.05 \text { level } \\
\text { "-MacKinnon-Haug-Michelis (1999) p-values }\end{array}$} \\
\hline \multicolumn{5}{|c|}{ Unrestricted Cointograting Cootticients (normalized by b" $\mathrm{S} 11^{*} \mathrm{~b}-1$ ): } \\
\hline $\begin{array}{c}\text { MRET } \\
22.55791 \\
8.009662 \\
\end{array}$ & $\begin{array}{c}\text { EXT } \\
393.1464 \\
-333.5604 \\
\end{array}$ & & & \\
\hline \multicolumn{5}{|c|}{ Unrestricted Adiustment Coefficients (alpha): } \\
\hline $\begin{array}{c}\text { D(MAET) } \\
\text { D(EXT) } \\
\end{array}$ & $\begin{array}{l}-0.050680 \\
-0.000777 \\
\end{array}$ & $\begin{array}{r}-0.013683 \\
0.000866 \\
\end{array}$ & & \\
\hline 1 Cointegrating & quation(s): & Loq likelihood & 733.2511 & \\
\hline $\begin{array}{c}\text { Normalized coin } \\
\text { MAET } \\
\text { 1.000000 }\end{array}$ & $\begin{array}{l}\text { Erating coeffi } \\
\text { EXT } \\
(2,42831 \\
(2.76028)\end{array}$ & nts (standard e & ror in parenthes & \\
\hline $\begin{array}{l}\text { Adiustment coet } \\
\text { D(MRET) } \\
\text { D(EXT) }\end{array}$ & $\begin{array}{l}\text { cients (stande } \\
-1.143240 \\
(0.18620) \\
-0.017538 \\
(0.00647)\end{array}$ & error in parent & eses) & \\
\hline
\end{tabular}

The results indicate that Akiake information criteria is lower in case of assumption which indicates that equations are quadratic in nature and have trend and intercept. Further Schwarz criterion is also indicating that results of the former are correct. Thus we will carry the co integration test assuming trend and intercept in quadratic form for establishing long term relationship. The test result under this assumption is as follows: 6.2 Johansen Co integration Test Summary

Table 1.5

\begin{tabular}{|c|c|c|c|c|c|}
\hline \multicolumn{6}{|c|}{ 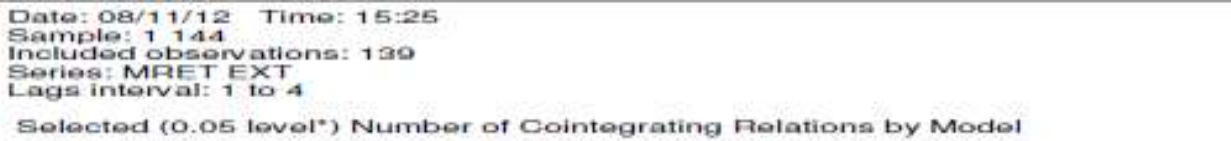 } \\
\hline $\begin{array}{c}\text { Data Trond: } \\
\text { Test Trpe } \\
\text { Trece } \\
\text { Max-Eig }\end{array}$ & $\begin{array}{l}\text { None } \\
\text { No intercept } \\
\text { No Trond } \\
\frac{2}{2}\end{array}$ & $\begin{array}{l}\text { Nono } \\
\text { Intercent } \\
\text { No Trond } \\
\frac{2}{2} \\
\end{array}$ & $\begin{array}{c}\text { Linear } \\
\text { Intercest } \\
\text { No Trond } \\
\frac{2}{2} \\
\end{array}$ & $\begin{array}{c}\text { Linoar } \\
\text { Intercept } \\
\text { Trond } \\
1 \\
1\end{array}$ & $\begin{array}{l}\text { Ouadratic } \\
\text { intercept } \\
\text { Trond } \\
\frac{2}{2} \\
\qquad\end{array}$ \\
\hline \multicolumn{6}{|c|}{$\begin{array}{l}\text { - Critical valuos based on Mackinnon-Haug-Micholis (1900) } \\
\text { Information Critoria by Rank and Modol }\end{array}$} \\
\hline $\begin{array}{l}\text { Data Trond: } \\
\text { Pank or: } \\
\text { No, of CEa }\end{array}$ & $\begin{array}{l}\text { Nono } \\
\text { No Intoroopt } \\
\text { No Trend }\end{array}$ & $\begin{array}{l}\text { Nono } \\
\text { Intoroopt } \\
\text { No Trend }\end{array}$ & $\begin{array}{l}\text { Linoar } \\
\text { Litorospt } \\
\text { No Trend }\end{array}$ & $\begin{array}{l}\text { Linoar } \\
\text { Intoroopt } \\
\text { Trend }\end{array}$ & $\begin{array}{l}\text { Quadratic } \\
\text { Interoopt } \\
\text { Trend }\end{array}$ \\
\hline $\begin{array}{l}0 \\
1 \\
2\end{array}$ & $\begin{array}{l}\text { Log Likelihoo } \\
700.5355 \\
723.4706 \\
720.0741\end{array}$ & $\begin{array}{l}1 \text { by Rank }(\text { re } \\
709.5355 \\
733.1584 \\
730.0140\end{array}$ & $\begin{array}{l}\text { We) and Mode } \\
709.6206 \\
739.1653 \\
730.0140\end{array}$ & $\begin{array}{l}\text { (columna) } \\
700.6296 \\
739.2595 \\
739.1247\end{array}$ & $\begin{array}{l}700.8358 \\
720.2511 \\
739.1247\end{array}$ \\
\hline $\begin{array}{l}0 \\
1 \\
2\end{array}$ & $\begin{array}{l}\text { Akaike inform } \\
-0.978928 \\
-10.12100 \\
-10.14207\end{array}$ & $\begin{array}{l}\text { ation Criteria } \\
-9.978928 \\
-10.24658 \\
-10.25910^{-}\end{array}$ & $\begin{array}{l}\text { by Rank frow } \\
-9.951508 \\
-10.23259 \\
-10.25619 .\end{array}$ & $\begin{array}{l}\text { 3) and Model } \\
-9.951506 \\
-10.21927 \\
-10.23201\end{array}$ & $\begin{array}{l}\text { (columns) } \\
-9.925694 \\
-10.20505 \\
-10.23201 \\
\end{array}$ \\
\hline $\begin{array}{l}0 \\
1 \\
2\end{array}$ & $\begin{array}{l}\text { Sohwarz Grit } \\
-9.641147 \\
-9.60652 \\
-9.635401\end{array}$ & $\begin{array}{l}\text { ria by Pank } \\
-9.641477 \\
-9.803546^{\circ} \\
-9.710300\end{array}$ & $\begin{array}{l}\text { ows) and } M c \\
-9.571502 \\
-9.768146 \\
-9.710300\end{array}$ & $\begin{array}{l}\text { dol (columns) } \\
\text { - } 0.671502 \\
-9.733713 \\
-9.640803\end{array}$ & $\begin{array}{r}-9.603468 \\
-9.698380 \\
-9.640893\end{array}$ \\
\hline
\end{tabular}


The results indicate that Null hypothesis that indicates no long term relationship exists is rejected by significant p-value of 0.000 . Thus the results clearly indicate that long term relationship exists in between exchange rate and market returns. Thus after establishing long term relationship, we will see whether exchange rate has short term impact on market returns. Thus we will use the co integrating equation and check it for Vector Error Correction.

6.3 Vector Error Correction Model (VECM)

The results of VECM are summarized in table 1.6

Table 1.6

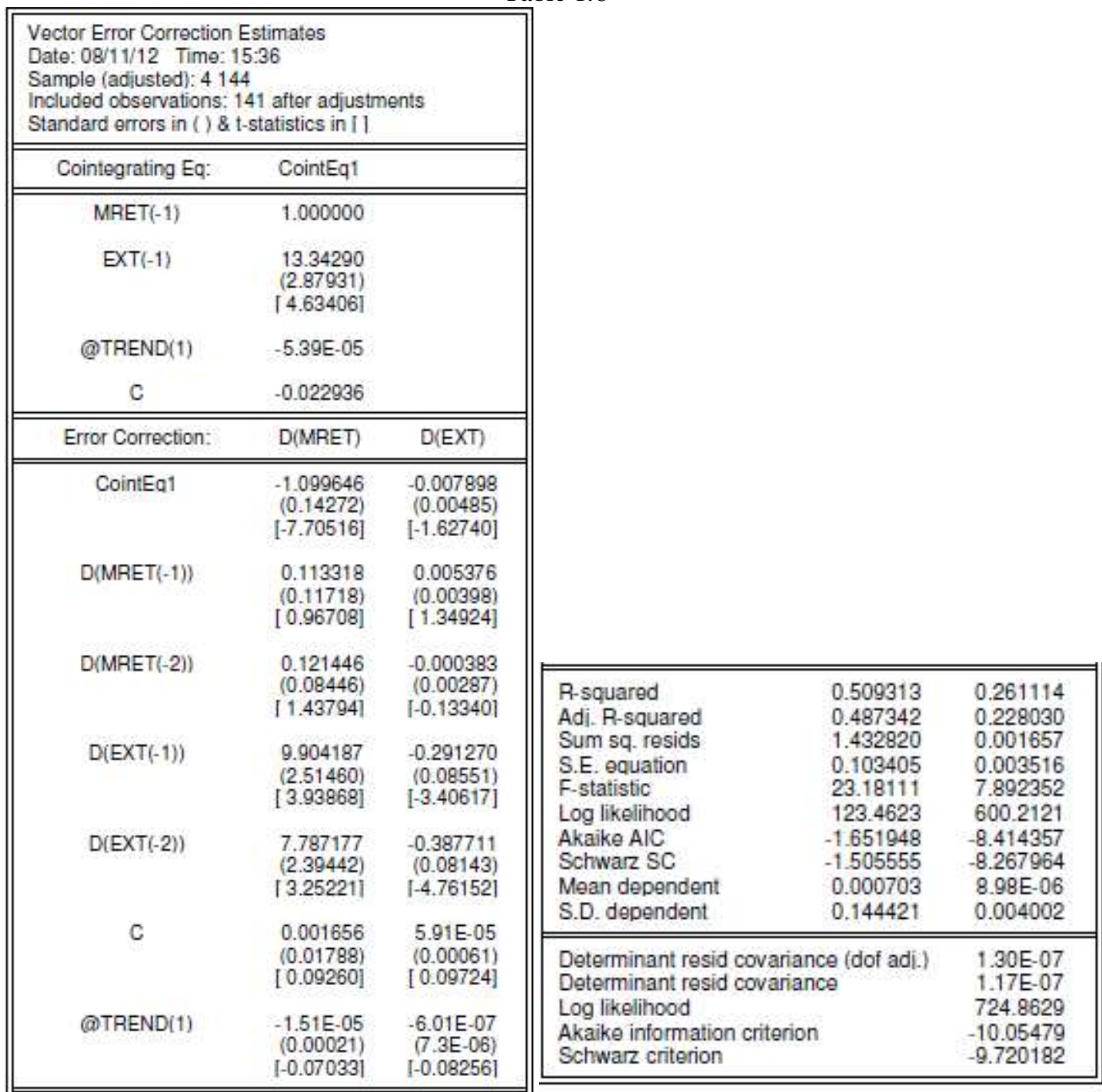

The results indicate that the intercept of co integrating equation is negative and significant. This validates the long term relationship. The coefficients of exchange rates with lag 1 and 2 are significant that indicates the impact of short run exchange rate movements of previous 1 and 2 months respectively has significant impact on Pakistani stock market returns. However we have t-values of the error correction terms and no p-values. Thus to obtain p-values and to further confirm short run impact of exchange rate on market return, we will following VECM equation and conduct Ordinary Least square Analysis at 95\% confidence interval:

(3) $\mathrm{D}(\mathrm{MRET})=\mathrm{C}(1) *(\operatorname{MRET}(-1)+13.3428963975 * \mathrm{EXT}(-1)-5.38602779704 \mathrm{e}-05 * @ \mathrm{TREND}(1)-$ $0.0229364536928)+\mathrm{C}(2) * \mathrm{D}(\operatorname{MRET}(-1))+\mathrm{C}(3) * \mathrm{D}(\mathrm{EXT}(-1))+\mathrm{C}(4) * \mathrm{D}(\mathrm{MRET}(-2))+\mathrm{C}(5) * \mathrm{D}(\mathrm{EXT}(-$ $2))+\mathrm{C}(6)+\mathrm{C}(7) * @ \mathrm{TREND}(1)$

6.4 OLS Results:

The OLS results are summarized as follows; 
Table 1.7 (VECM regression)

\begin{tabular}{|c|c|c|c|c|}
\hline \multicolumn{5}{|c|}{ 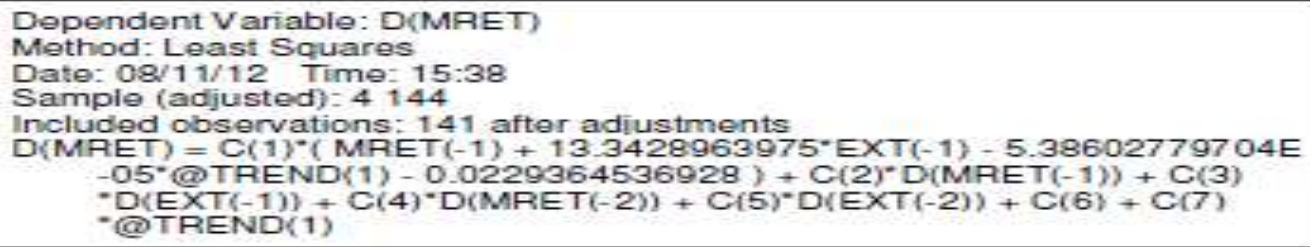 } \\
\hline & Coefficient & Std. Error & t-Statistic & Prob. \\
\hline $\begin{array}{l}C(1) \\
C(2) \\
C(3) \\
C(4) \\
C(5) \\
C(6) \\
C(7)\end{array}$ & $\begin{array}{r}-1.099646 \\
0.113318 \\
9.904187 \\
0.121446 \\
7.787177 \\
0.001656 \\
-1.51 E-05\end{array}$ & $\begin{array}{l}0.142716 \\
0.117175 \\
2.514596 \\
0.084458 \\
2.394424 \\
0.017884 \\
0.000214\end{array}$ & $\begin{array}{r}-7.705155 \\
0.967081 \\
3.938680 \\
1.437944 \\
3.252213 \\
0.092603 \\
-0.070335\end{array}$ & $\begin{array}{l}0.0000 \\
0.3352 \\
0.0001 \\
0.1528 \\
0.0014 \\
0.9264 \\
0.9440\end{array}$ \\
\hline $\begin{array}{l}\text { A-squared } \\
\text { Adjusted R-squared } \\
\text { SE. of regression } \\
\text { Sum squared resid } \\
\text { Log likelihood } \\
\text { F-statistic } \\
\text { Prob(F-statistic) }\end{array}$ & $\begin{array}{l}0.509313 \\
0.487342 \\
0.103405 \\
1.432820 \\
123.4623 \\
23.18111 \\
0.000000\end{array}$ & \multicolumn{2}{|c|}{$\begin{array}{l}\text { Mean dependent var } \\
\text { S.D. dependent var } \\
\text { Akaike info criterion } \\
\text { Schwarz criterion } \\
\text { Harnman-Quinn criter. } \\
\text { Durbin-Watson stat. }\end{array}$} & $\begin{array}{r}0.000703 \\
0.144421 \\
-1.651948 \\
-1.505555 \\
-1.592459 \\
2.049001\end{array}$ \\
\hline
\end{tabular}

The results of OLS regression indicates that $\mathrm{C}(3)$ and $\mathrm{C}(5)$ which are the co-efficient of short term change in exchange rate has significant impact on change in market return where $C(6)$ is the co-efficient of the system equation. However, to further test the existence of impact of exchange rate change, we will conduct Wald test using following hypothesis:

$\mathrm{C}(3)=\mathrm{C}(5)=0$, the null hypothesis assumes that short term exchange rates have no significant impact on market returns.

Table: 1.8

\begin{tabular}{||lccc||}
\hline $\begin{array}{l}\text { W Wald Test: } \\
\text { Equation: Untitled }\end{array}$ & & \\
\hline \hline Test Statistic & Value & df & Probability \\
\hline \hline F-statistic & 9.715047 & $(2,134)$ & 0.0001 \\
Chi-square & 19.43009 & 2 & 0.0001 \\
\hline \hline & & \\
Null Hypothesis: $\mathrm{C}(3)=\mathrm{C}(5)=0$ & & \\
Null Hypothesis Summary: & & Value & Std. Err. \\
\hline \hline Normalized Restriction $(=0)$ & 9.904187 & 2.514596 \\
\hline \hline C(3) & 7.787177 & 2.394424 \\
C(5) & & \\
Restrictions are linear in coefficients. & \\
\hline
\end{tabular}

The p-values of .000 indicate that we will reject null hypothesis and accept the alternate. Thus we can safely say that exchange rates have short term impact on market returns.

\section{Conclusion}

The study was conducted in an effort to understand the impact of exchange rate on stock market returns. The primary purpose of the study was to understand short run sensitivity of returns to changes in exchange rate. The reason for this is because in Pakistan, investments in stock exchanges are short term and most of investors liquidate their stocks within year. VECM analysis was conducted that indicates that exchange rates have significant impact on stock market returns. The results indicate that in the short run, market correct itself to the changes in exchange rate to be in equilibrium. This finding has implications for government and industry. An appreciation of Pakistani rupee will cause the returns to rise and vice versa. Thus if there is, fluctuations in rupee, the exchange rate will adversely affect the change in market returns. Thus for a stable stock market, exchange rate has to be maintained in a favorably territory. 


\section{References:}

[1] Bahmani-Oskooee, R. and Sohrabian, A. (1992). Stock prices and the effective exchange rate of the dollar. Applied Economics, Vol. 24 (4), pp. 193-207

[2] Bremer, M. and Hiraki, T. (1999). Volume and individual security returns on the Tokyo Stock Exchange, Pacific Basin Finance Journal, Vol. 7 (3-4) pp. $351-370$.

[3] Chiang, T. and Doong, S. (1999). Empirical analysis of real and financial volatilities on stock excess returns: evidence from Taiwan industrial data, Global Finance Journal, Vol. 10 (2), pp. 187 - 200.

[4] Cos, J., Ingersoll, J. and Ross, S. (2985). An intertemporal general equilibrium model of asset prices, Econometrica, Vol. 53, pp. $363-384$.

[5] Ferriera, M. and Santa-Clara, P. (2011). Forecasting stock market returns: The sum of the parts is more than the whole, Journal of Financial Economics, Vol. 100 (3), pp. $514-537$.

[6] Kim, K. (2003). Dollar exchange rate and stock price: evidence from multivariate cointegration and error correction model, Review of Financial Economics, Vol. 12 (3), pp. 301- 313.

[7] Lin, C. (2012). The comovement between exchange rates and stock prices in the Asian emerging markets, International Review of Economics and Finance, Vol. 22 (1), pp. $161-172$.

[8] Marey, P. (2004). Exchange rate expectations: controlled experiments with artificial traders, Journal of International Money and Finance, Vol. 23 (2), pp. 283 - 304.

[9] Tsen, W. (2011). The real exchange rate determination: An empirical investigation, International Review of Economics and Finance, Vol. 20 (4), pp. $800-811$.

[10] Wu et al. (2012). Interrelationship between Philippine Stock Exchange Index and USD Exchange Rate, Pocedia, Vol. 40 , pp. 786 782.

[11] Yau, H. and Nieh, C. (2008). Testing for cointegration with threshold effect between stock prices and exchange rates in Japan and Taiwan, Japan and the World Economy, Vol. 21 (3), pp. $292-300$. 